\title{
Response of benthic meiofauna to nutrient enrichment of experimental marine ecosystems
}

\author{
Bertil Widbom ${ }^{1}$, Ragnar Elmgren ${ }^{2}$ \\ 1 Department of Zoology, University of Stockholm, S-106 91 Stockholm, Sweden \\ ${ }^{2}$ Department of Zoology and Askö Laboratory, University of Stockholm, S-106 91 Stockholm, Sweden
}

\begin{abstract}
The long-term (2.4 yr) response of benthic meiofauna to eutrophication of experimental marine ecosystems was studied at the Marine Ecosystems Research Laboratory, Graduate School of Oceanography, University of Rhode Island (USA). Ammonium, phosphate and silicate were added daily to the mesocosms in a logarithmic progression $(0 \times, 1 \times, 2 \times, 4 \times, 8 \times, 16 \times$ and $32 \times)$, with the $1 \times$ addition being $\mathrm{N}=2.88, \mathrm{P}=0.225, \mathrm{Si}=0,205 \mathrm{mmol} \mathrm{m} \mathrm{m}^{-2} \mathrm{~d}^{-1}$. Phytoplankton production and biomass in the tanks increased with increasing nutrient enrichment. The benthic community gave a quantitatively less marked response to the gradient of nutrient input. The meiofauna showed remarkably little response in terms of total biomass and abundance, but significant effects were found on major taxa, leading to a changed meiofauna community structure. Nematode and juvenile polychaete abundance increased with increasing nutrient input, especially in early summer, whereas kinorhynchs, ostracods, harpacticoids and juvenile bivalves decreased. The lack of a positive biomass response of the total meiofauna in the enriched tanks suggests that the meiofauna was limited not only by the availability of food, but also by biotic interactions.
\end{abstract}

\section{INTRODUCTION}

Eutrophication of coastal marine areas has received increasing attention in recent years, both in Europe (Rosenberg 1985) and North America (Goldberg 1982). Enhanced concentrations of inorganic nutrients and heavy plankton blooms have been recorded, as has oxygen deficiency in the bottom water below the pycnocline, e.g. in the southeastern Kattegat (Rosenberg 1985), and the Baltic Sea (Lassig 1987), and in Chesapeake Bay (Officer et al. 1984). Another common effect of eutrophication and organic enrichment is an increase in benthic macrofaunal biomass (Pearson \& Rosenberg 1978). The mechanisms by which different compartments of a coastal marine ecosystem react to an increased input of inorganic nutrients are still, however, incompletely understood (Nixon et al. 1986). This is particularly true for the benthic meiofauna.

Studies of the effects of environmental perturbations on marine ecosystems have in recent years been stimulated by the use of mesocosms - large enclosures containing captive experimental ecosystems (Steele 1979, Donaghay 1984). At the Marine Ecosystems Research Laboratory (MERL), of the Graduate School of Oceanography, University of Rhode Island, USA, a long-term ecosystem level eutrophication experiment was carried out from 1981 to 1983 (Nixon et al. 1984. 1986, Grassle et al. 1985, Oviatt et al. 1986). We studied the benthic meiofauna communities in the MERL mesocosms during this experiment, and examine 3 basic questions: (1) How do major meiofaunal taxa respond to an increased input of nutrients and the resulting increase in sedimentation of seston? (2) Were the meiofauna populations in the MERL mesocosms mainly limited by food or by other factors, such as disturbance or predation from benthic macrofauna? (3) Can the gross taxonomic composition of benthic meiofauna communities be used as an indicator of eutrophication and organic enrichment?

\section{MATERIALS AND METHODS}

The mesocosms. The MERL mesocosms are designed to simulate shallow, unstratified, temperate marine ecosystems, such as Narragansett Bay, on which they are situated (Pilson et al. 1980). Each mesocosm contains a water column underlain by a tray with sediment (Fig. 1). The benthos is predominantly heterotrophic most of the year, as in Narragansett Bay. Water temper- 


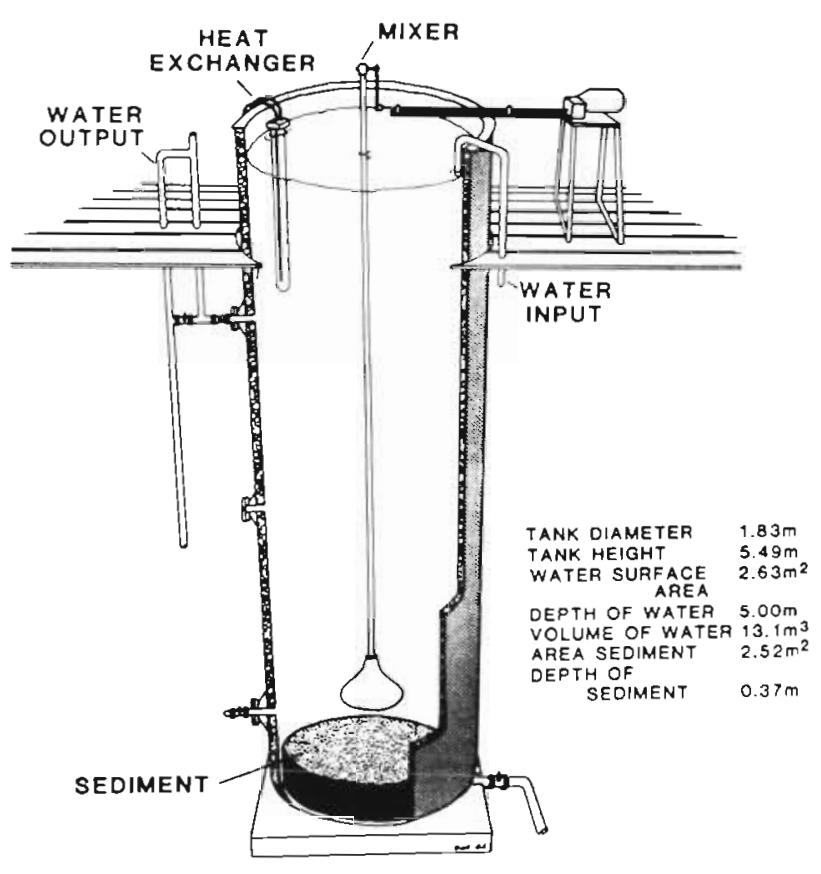

Fig. 1. Cross section of a MERL mesocosm showing input and output pipes, mixer, sediment container and heat exchanger. (Drawn by E. Klos)

ature in the tanks was maintained within $2 \mathrm{C}^{\circ}$ of that in the Bay, with maxima of ca $22^{\circ} \mathrm{C}$ in July-August and minima of ca $1{ }^{\circ} \mathrm{C}$ in January-February (Frithsen et al. $1985 b)$. A vertical plunger simulated the tidal mixing in the Bay (Nixon et al. 1980). The mean suspended loads in the mesocosms were similar to those in the Bay (ca $3 \mathrm{mg} \mathrm{l}^{-1}$; Oviatt et al. 1986). Seawater ( 27 to $31 \%$ S) was pumped in from $2 \mathrm{~m}$ above the bottom at a $4 \mathrm{~m}$ deep site, giving a turnover time of $27 \mathrm{~d}$.

Sediment cores collected from a well-studied $7 \mathrm{~m}$ deep site in mid Narragansett Bay (Rudnick et al. 1985, Grassle et al. 1985), using a $0.25 \mathrm{~m}^{2}$ USNEL spade box corer (Hunt \& Smith 1983), were placed in the tanks in April 1981. The sediment was $18 \%$ sand, $60 \%$ silt and $23 \%$ clay particles by weight (mean grain size $28 \mu \mathrm{m}$ ), with $47 \%$ water content and $1.8 \%$ total carbon content (0 to $4 \mathrm{~cm}$ sediment depth; Lambert \& Oviatt 1986). The benthic macrofauna at this site is numerically dominated by 2 deposit feeders, the capitellid polychaete Mediomastus ambiseta (Hartman) and the bivalve Nucula annulata (Hampson) (Grassle et al. 1985).

The experiment. Six MERL mesocosm tanks received additions of nitrogen, phosphorus and silica as the inorganic salts $\mathrm{NH}_{4} \mathrm{Cl}, \mathrm{KH}_{2} \mathrm{PO}_{4}$ and $\mathrm{NaSiO}_{3} \cdot 9 \mathrm{H}_{2} \mathrm{O}$, in molecular ratios characteristic of sewage entering upper Narragansett Bay (12.80 N:1.00 P:0.91 Si; Nixon 1981). The lowest level $(1 \times)$ of nutrient addition $(\mathrm{N}=$ 7.57, $\mathrm{P}=0.591, \mathrm{Si}=0.54 \mathrm{mmol} \operatorname{tank}^{-1} \mathrm{~d}^{-1}$ ) corresponded to the estimated average daily per unit area input of dissolved inorganic nutrients into Narragansett
Bay from sewage and runoff. The other treatments were $2 \times, 4 \times, 8 \times, 16 \times$ and $32 \times$ multiples of this loading, approximately corresponding to the range of nutrient loadings found in natural systems (Nixon et al. 1986). Daily nutrient additions started on 1 June 1981 and continued until 26 September 1983. Three MERL mesocosms served as controls $(=0 \times)$. For detailed descriptions of the experimental setup, see Nixon et al. (1984) and Frithsen et al. (1985b, c, d). Water column characteristics (such as nutrients, oxygen, chlorophyll a, primary production and respiration) were measured during a mixing cycle, approximately weekly. Sediment porosity, Eh and benthic oxygen flux were measured seasonally throughout the experiment, as was sediment total carbon and nitrogen content during the last year (for methods see Lambert \& Oviatt 1986).

Meiofaunal methods. Ten sediment cores were taken in each mesocosm approximately every 2 mo from May 1981 through September 1983, using a stickmounted $5.07 \mathrm{~cm}^{2}$ flow-through corer (Frithsen et al. 1983). The meiofauna was examined in the samples from May, June and September 1981, January, June and September 1982, and June and September 1983. The sampling locations were pre-selected randomly, but avoiding overlap. Cores were sectioned into 0 to $2 \mathrm{~cm}$ and 2 to $6 \mathrm{~cm}$ sediment depth horizons, and preserved in $10 \%$ buffered seawater formalin with Rose Bengal $\left(0.2 \mathrm{~g} \mathrm{l}^{-1}\right)$. Meiofauna was counted only in the 0 to $2 \mathrm{~cm}$ layer, which usually contains about $60 \%$ of total meiofauna numbers in the Bay ( 75 to $100 \%$ of taxa other than nematodes and foraminiferans), and follows the overall seasonal abundance and biomass trends in Narragansett Bay well (Frithsen et al. 1985a, Rudnick et al. 1985). Sediment cores were sieved individually through 500 and $300 \mu \mathrm{m}$ sieves to extract the macrofauna. Animals retained on these sieves and belonging to taxa normally considered to be meiofaunal (i.e. Nematoda, Harpacticoida, Foraminifera, Halacarida, Ostracoda, Kinorhyncha and Turbellaria), as well as all animals passing the $300 \mu \mathrm{m}$ sieve and retained on the $40 \mu \mathrm{m}$ sieve, were counted as meiofauna. The sieved residue from all 10 cores from each tank on each occasion were pooled before the meiofauna was extracted by sieving through a series of sieves with mesh sizes 500,300,200, 100 and $40 \mu \mathrm{m}$. Before counting and sorting all meiofauna specimens into major taxa under a dissecting microscope at $25 \times$ magnification, the $300 \mu \mathrm{m}$ sieve fraction was subsampled $1 / 2$, the $200 \mu \mathrm{m}$ fraction $1 / 8$, nematodes in the $100 \mu \mathrm{m}$ fraction $3 / 64$, the rest of this fraction $1 / 8$, and the $40 \mu \mathrm{m}$ fraction $1 / 128$, using an Elmgren (1973) sample splitter. Meiofauna ash-free dry weight was estimated from abundance by means of sieve-mesh specific conversion factors (Widbom 1984).

Statistical analysis. In all statistical tests, meiofaunal 
Table 1. Selected environmental data. Macrofauna and sediment carbon data from Frithsen et al. (1985d); chlorophyll a values are averages for the preceeding month, calculated from Frithsen et al. (1985b)

\begin{tabular}{|c|c|c|c|c|c|c|c|}
\hline Load & $\begin{array}{l}\text { Water column } \\
\text { Chl a }\left(\mu \mathrm{g} \mathrm{l}^{-1}\right)\end{array}$ & $\begin{array}{l}\text { Sediment carbon } \\
\qquad(\% \text { of } d w)\end{array}$ & $\begin{array}{c}\text { Total macrof } \\
\text { biomass }\left(\mathrm{gC} \mathrm{m}^{-2}\right)\end{array}$ & Load & $\begin{array}{l}\text { Water column } \\
\text { Chl a }\left(\mu \mathrm{gl}^{-1}\right)\end{array}$ & $\begin{array}{l}\text { Sediment carbon } \\
(\% \text { of } d w)\end{array}$ & $\begin{array}{c}\text { Total macrof } \\
\text { biomass }\left(\mathrm{gC} \mathrm{m}^{-2}\right)\end{array}$ \\
\hline \multicolumn{4}{|c|}{ May 1981} & \multicolumn{4}{|c|}{ September 1982} \\
\hline $0 \times$ & 2 & - & - & $0 \times$ & 2 & 2.1 & 5.8 \\
\hline $0 \times$ & 2 & - & - & $0 \times$ & 3 & - & 6.7 \\
\hline $0 \times$ & 4 & - & - & $0 \times$ & 3 & 1.9 & 3.7 \\
\hline $1 \times$ & 2 & - & - & $1 \times$ & 2 & - & 12.5 \\
\hline $2 \times$ & 3 & - & - & $2 \times$ & 3 & - & 7.1 \\
\hline $4 \times$ & 1 & - & - & $4 \times$ & 6 & 1.9 & 1.9 \\
\hline $8 x$ & 2 & - & - & $8 x$ & 2 & 2.2 & 52.8 \\
\hline $16 \times$ & 3 & - & - & $16 x$ & 7 & 2.0 & 21.8 \\
\hline $32 x$ & 3 & - & - & $32 \times$ & 75 & - & 2.4 \\
\hline \multicolumn{4}{|c|}{ June 1981} & \multicolumn{4}{|c|}{ April 1983} \\
\hline $0 x$ & 5 & - & 4.5 & $0 x$ & 3 & 2.0 & - \\
\hline $0 \times$ & 7 & - & 4.3 & $0 \times$ & 4 & - & - \\
\hline $0 x$ & 7 & - & 5.0 & $0 x$ & 4 & - & - \\
\hline $1 \times$ & 6 & - & 5.6 & $1 \times$ & 10 & - & - \\
\hline $2 x$ & 16 & - & 4.3 & $2 \times$ & 18 & - & - \\
\hline $4 \times$ & 14 & - & 5.1 & $4 \times$ & 29 & 2.3 & - \\
\hline $8 x$ & 29 & - & 5.4 & $8 x$ & 36 & 2.5 & - \\
\hline $16 x$ & 21 & - & 7.0 & $16 x$ & 113 & 3.0 & - \\
\hline $32 x$ & 46 & - & - & $32 \times$ & 71 & 3.5 & - \\
\hline \multicolumn{4}{|c|}{ September 1981} & \multicolumn{4}{|c|}{ June 1983} \\
\hline $0 \times$ & 5 & - & 9.3 & $0 \times$ & 2 & 2.3 & 11.5 \\
\hline $0 x$ & 4 & - & 2.5 & $0 x$ & 6 & - & 3.6 \\
\hline $0 x$ & 4 & - & 7.6 & $0 \times$ & 3 & - & 6.1 \\
\hline $1 x$ & 11 & - & 1.2 & $1 x$ & 2 & - & 15.5 \\
\hline $2 \times$ & 10 & - & 19.3 & $2 \times$ & 24 & - & 0.3 \\
\hline $4 x$ & 6 & - & 20.4 & $4 \times$ & 17 & 2.3 & 0.7 \\
\hline $8 x$ & 2 & - & 17.8 & $8 \times$ & 3 & 2.4 & 32.4 \\
\hline $16 \times$ & 8 & - & 13.9 & $16 x$ & 43 & 2.7 & 2.0 \\
\hline $32 x$ & 81 & - & 25.0 & $32 x$ & 82 & 5.0 & 60.5 \\
\hline \multicolumn{4}{|c|}{ January 1982} & \multicolumn{4}{|c|}{ September 1983} \\
\hline $0 x$ & 8 & - & 6.2 & $0 \times$ & 3 & 2.2 & 16.9 \\
\hline $0 \times$ & 11 & - & 2.9 & $0 x$ & 8 & 2.1 & 3.4 \\
\hline $0 x$ & 13 & - & 3.1 & $0 x$ & 4 & 2.1 & 6.7 \\
\hline $1 x$ & 21 & - & 15.3 & $1 \times$ & 6 & 2.1 & 16.3 \\
\hline $2 x$ & 6 & - & 10.4 & $2 \times$ & 10 & 2.7 & 9.2 \\
\hline $4 \times$ & 61 & - & 15.2 & $4 \times$ & 12 & 2.2 & 5.5 \\
\hline $8 x$ & 8 & - & 24.2 & $8 x$ & 6 & 2.3 & 18.1 \\
\hline $16 x$ & 61 & - & 29.2 & $16 \times$ & 18 & 2.4 & 7.2 \\
\hline $32 x$ & 74 & - & 8.4 & $32 x$ & 25 & 3.7 & 8.8 \\
\hline \multicolumn{8}{|c|}{ June 1982} \\
\hline $0 \times$ & 2 & 2.2 & 6.4 & & & & \\
\hline $0 x$ & 2 & - & 11.6 & & & & \\
\hline $0 \times$ & 3 & - & 9.6 & & & & \\
\hline $1 \times$ & 6 & - & 24.4 & & & & \\
\hline $2 x$ & 3 & - & 8.5 & & & & \\
\hline $4 \times$ & 6 & 2.1 & 16.4 & & & & \\
\hline $8 x$ & 2 & 2.3 & 36.0 & & & & \\
\hline $16 \times$ & 91 & - & 10.2 & & & & \\
\hline $32 x$ & 69 & 3.1 & 11.6 & & & & \\
\hline
\end{tabular}

data from 19 June 1981 have been considered as preexperimental, since the meiofauna populations could hardly respond to the nutrient enrichment in $18 \mathrm{~d}$. The abundance and biomass of total meiofauna and abundance of individual taxa were tested against the gradient of nutrient loading and against experimental time (year), using Spearman's coefficient of rank correlation (Sokal \& Rohlf 1981). For experimental data the tests against nutrient loading were performed on mean ranks (first ranking the tanks at each date, then averaging over dates) for the first (Sep 1981 to Jun 1982) and second experimental year (Sep 1982 to Sep 1983) sepa- 
rately, as well as for the whole experimental period. Preexperimental data were ranked only for June 1981, since not all tanks were sampled in May 1981. The tests against time were performed on data from June and September each year, ranked for each tank separately. For 2 taxa showing an appreciable response only in the most highly enriched tanks, pairwise comparisons were made with 2-tailed Mann-Whitney U-test (Sokal \& Rohlf 1981) on mean ranks, comparing the most highly loaded tanks $(8 \times, 16 \times$ and $32 \times)$ with controls and lower loadings combined. Meiofauna community structure was studied by ordinating all samples (non-normalized data) with a principal components analysis (SAS Institute 1982).

\section{RESULTS}

\section{Environmental data}

The phytoplankton communities in the tanks responded with increasing chlorophyll a content and primary production up the nutrient addition gradient (Table 1; Nixon et al. 1986, Oviatt et al. 1986), with the exception of the $8 \times$ tank, where comparatively low such values were obtained from September 1981 on. This was probably due to the rapid development in this tank of a very dense population of the suspensionfeeding bivalve Mulinia lateralis (Say) (up to $10^{5}$ ind. $\mathrm{m}^{-2}$ in July 1981; Frithsen et al. 1985d). Water column oxyger concentrations alternated between super-saturation (most often during winter-spring blooms) and under-saturation (mostly from mid-summer to autumn). The amplitude of these oscillations increased with increasing nutrient input (Frithsen et al. 1985b, Oviatt et al. 1986).

Total sediment carbon $(0$ to $2 \mathrm{~cm}$ ) showed gradually increasing values up the nutrient enrichment gradient in April-June. During other periods only the $32 \times$ tank consistently showed values appreciably higher than the control tanks (Table 1). The other sediment variables measured at the end of the experiment also indicated greatest enrichment in the $32 \times$ tank from June 1982 onwards (Frithsen et al. 1985d).

The total macrofaunal biomass and benthic nighttime respiration initially showed slowly increasing values up the nutrient addition gradient, but from winter 1981/82 on the biomass response disappeared (Table 1; Frithsen et al. 1985d, Nixon et al. 1986). The total macrofauna abundance, however, peaked in the $32 \times$ tank, with very high numbers of small polychaetes. During the first year this peak consisted of the capitellid Mediomastus ambiseta (Nixon et al. 1984, Grassle et al. 1985), and later of the spionids Streblospio benedicti (Webster) and Polydora ligni (Webster) (Frithsen et al. 1985d).

\section{Meiofaunal taxa}

Abundance and biomass of total meiofauna, and the numerically dominating nematodes, showed a general decline with time, which was statistically significant in the control tanks, and for biomass also in loaded tanks (Fig. 2; Table 2). This trend was broken by high total abundances of 13 to $14 \times 10^{6}$ ind. $\mathrm{m}^{-2}$ and biomasses in some highly productive tanks in June 1982 and 1983.
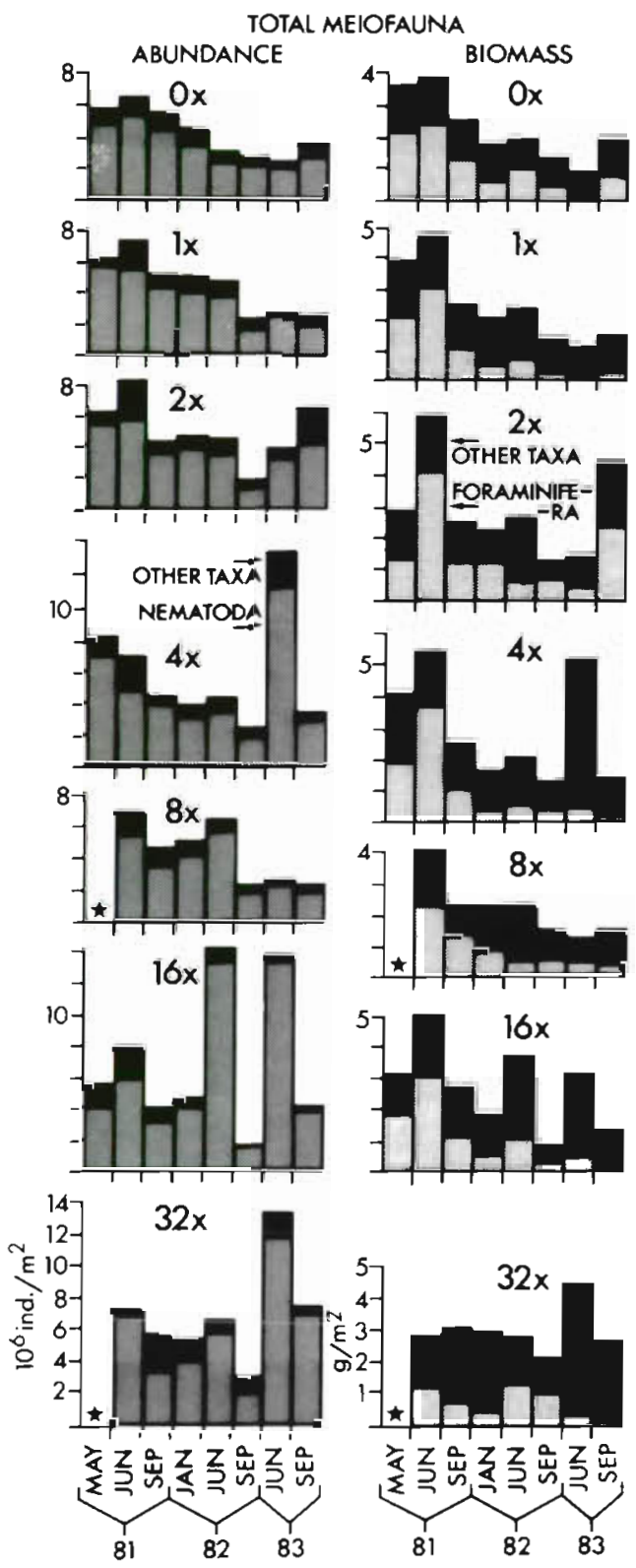

Fig. 2. Total meiofauna abundance $\left(10^{6}\right.$ ind $\left.\mathrm{m}^{-2}\right)$ and ash-free dry weight $\left(\mathrm{g} \mathrm{m}^{-2}\right)$ from the different nutrient addition treatments. ( $\star$ ) No data

resulting in a significant positive treatment effect for nematodes (Table 2), and a biomass peak in the $2 x$ tank in September 1983. Low values were noted in the 
Table 2. Values of Spearman's coefficient of rank correlation $\left(I_{s}\right)$ from tests of meiofauna abundance and biomass against the gradient of nutrient enrichment and against experimental time (year), together with corresponding $p$-values (in brackets). Asterisks indicate level of statistical significance: ${ }^{*} p<0.05 ; \cdots p<0.01 ; \cdots p<0.001$

\begin{tabular}{|c|c|c|c|c|c|c|}
\hline & \multicolumn{4}{|c|}{ Nutrient load } & \multicolumn{2}{|c|}{ Time } \\
\hline & Pre-expt & Expt Year 1 & Expt Year 2 & Expt total & Control tanks & Loaded tanks \\
\hline Foraminifera (monothalamous) & $\begin{array}{r}0.186 \\
(0.598)\end{array}$ & $\begin{array}{l}-0.043 \\
(0.904)\end{array}$ & $\begin{array}{l}-0.579 \\
(0.102)\end{array}$ & $\begin{array}{l}-0.492 \\
(0.164)\end{array}$ & $\begin{array}{l}-0.795 \\
(0.001)^{\cdots}\end{array}$ & $\begin{array}{c}-0.562 \\
(<0.001)\end{array} \cdots$ \\
\hline Foraminifera (polyth. calc.) & $\begin{array}{l}-0.407 \\
(0.250)\end{array}$ & $\begin{array}{l}-0.170 \\
(0.630)\end{array}$ & $\begin{array}{l}-0.502 \\
(0.156)\end{array}$ & $\begin{array}{l}-0.407 \\
(0.250)\end{array}$ & $\begin{array}{l}-0.598 \\
(0.014)^{\circ}\end{array}$ & $\begin{array}{c}-0.786 \\
(<0.001)\end{array} \cdots$ \\
\hline Foraminifera (polyth. aren.) & $\begin{array}{r}0.390 \\
(0.270)\end{array}$ & $\begin{array}{l}-0.744 \\
(0.035)^{\circ}\end{array}$ & $\begin{array}{l}-0.658 \\
(0.063)\end{array}$ & $\begin{array}{l}-0.915 \\
(0.010)^{\circ}\end{array}$ & $\begin{array}{l}-0.086 \\
(0.723)\end{array}$ & $\begin{array}{l}-0.353 \\
(0.037)\end{array}$ \\
\hline Kinorhyncha & $\begin{array}{r}0.068 \\
(0.848)\end{array}$ & $\begin{array}{l}-0.434 \\
(0.220)\end{array}$ & $\begin{array}{l}-0.746 \\
(0.035)\end{array}$ & $\begin{array}{l}-0.661 \\
(0.062)\end{array}$ & $\begin{array}{r}0.020 \\
(0.935)\end{array}$ & $\begin{array}{l}-0.316 \\
(0.062)\end{array}$ \\
\hline Nematoda & $\begin{array}{r}0.373 \\
(0.292)\end{array}$ & $\begin{array}{r}0.402 \\
(0.256)\end{array}$ & $\begin{array}{r}0.536 \\
(0.129)\end{array}$ & $\begin{array}{c}0.931 \\
(0.009)^{\circ}\end{array}$ & $\begin{array}{l}-0.677 \\
(0.005)\end{array}$ & $\begin{array}{l}-0.097 \\
(0.565)\end{array}$ \\
\hline Polychaeta & $\begin{array}{l}-0.547 \\
(0.122)\end{array}$ & $\begin{array}{c}0.698 \\
(0.048)^{\circ}\end{array}$ & $\begin{array}{r}0.186 \\
(0.598)\end{array}$ & $\begin{array}{r}0.664 \\
(0.060)\end{array}$ & $\begin{array}{r}-0.279 \\
(0.250)\end{array}$ & $\begin{array}{r}0.209 \\
(0.216)\end{array}$ \\
\hline Harpacticoida & $\begin{array}{r}0.220 \\
(0.533)\end{array}$ & $\begin{array}{l}-0.552 \\
(0.119)\end{array}$ & $\begin{array}{r}-0.111 \\
(0.753)\end{array}$ & $\begin{array}{l}-0.111 \\
(0.753)\end{array}$ & $\begin{array}{r}0.086 \\
(0.723)\end{array}$ & $\begin{array}{l}-0.031 \\
(0.856)\end{array}$ \\
\hline Ostracoda & $\begin{array}{r}0.649 \\
(0.066)\end{array}$ & $\begin{array}{l}-0.746 \\
(0.035)^{\circ}\end{array}$ & $\begin{array}{l}-0.574 \\
(0.104)\end{array}$ & $\begin{array}{l}-0.644 \\
(0.068)\end{array}$ & $\begin{array}{c}0.595 \\
(0.014)^{\circ}\end{array}$ & $\begin{array}{l}-0.476 \\
(0.005)^{\cdots}\end{array}$ \\
\hline Bivalvia & $\begin{array}{l}-0.443 \\
(0.211)\end{array}$ & $\begin{array}{l}-0.863 \\
(0.015)\end{array}$ & $\begin{array}{l}-0.868 \\
(0.014)\end{array}$ & $\begin{array}{l}-0.864 \\
(0.014)^{\circ}\end{array}$ & $\begin{array}{c}-0.846 \\
(<0.001)\end{array} \cdots$ & $\begin{array}{c}-0.777 \\
(<0.001)\end{array} \cdots$ \\
\hline Total meiofauna abundance & $\begin{array}{r}0.203 \\
(0.565)\end{array}$ & $\begin{array}{r}0.395 \\
(0.264)\end{array}$ & $\begin{array}{r}0.364 \\
(0.304)\end{array}$ & $\begin{array}{r}0.556 \\
(0.116)\end{array}$ & $\begin{array}{l}-0.757 \\
(0.002) \cdots\end{array}$ & $\begin{array}{l}-0.199 \\
(0.240)\end{array}$ \\
\hline Total meiofauna biomass & $\begin{array}{l}-0.008 \\
(0.981)\end{array}$ & $\begin{array}{r}0.593 \\
(0.093)\end{array}$ & $\begin{array}{r}0.255 \\
(0.470)\end{array}$ & $\begin{array}{r}0.661 \\
(0.062)\end{array}$ & $\begin{array}{l}-0.717 \\
(0.003) \cdots\end{array}$ & $\begin{array}{l}-0.395 \\
(0.020)^{\circ}\end{array}$ \\
\hline Permanent meiofauna biomass & $\begin{array}{r}0.000 \\
(1.000)\end{array}$ & $\begin{array}{r}0.434 \\
(0.220)\end{array}$ & $\begin{array}{r}0.068 \\
(0.847)\end{array}$ & $\begin{array}{r}0.373 \\
(0.292)\end{array}$ & $\begin{array}{l}-0.677 \\
(0.005) \cdots\end{array}$ & $\begin{array}{l}-0.483 \\
(0.004) \cdots\end{array}$ \\
\hline Temporary meiofauna biomass & $\begin{array}{l}-0.323 \\
(0.360)\end{array}$ & $\begin{array}{r}0.462 \\
(0.192)\end{array}$ & $\begin{array}{r}0.136 \\
(0.701)\end{array}$ & $\begin{array}{r}0.373) \\
(0.270)\end{array}$ & $\begin{array}{l}-0.561 \\
(0.021)^{\circ}\end{array}$ & $\begin{array}{l}-0.302 \\
(0.074)\end{array}$ \\
\hline Nem./cop.-ratio & $\begin{array}{l}-0.220 \\
(0.533)\end{array}$ & $\begin{array}{c}0.698 \\
(0.048)^{\circ}\end{array}$ & $\begin{array}{r}0.528 \\
(0.136)\end{array}$ & $\begin{array}{c}0.698 \\
(0.048)^{\circ}\end{array}$ & $\begin{array}{l}-0.518 \\
(0.033)\end{array}$ & $\begin{array}{r}-0.240 \\
(0.156)\end{array}$ \\
\hline
\end{tabular}

$8 \times$ tank, especially during the last year, coinciding with its low chlorophyll a content and primary production. Neither total abundance nor biomass showed a significant response to the nutrient addition gradient (Table 2).

Foraminiferans (Fig. 3) and juvenile bivalves (Fig. 5) also showed a significant decreasing trend throughout the experiment (Table 2). For both these taxa the decline was broken by a sudden peak in September 1983, for juvenile bivalves (normally dominated by Nucula annulata), caused by a heavy spatfall of Mulinia lateralis. Like in mid Narragansett Bay (Said 1951) the foraminiferans in the tanks were highly dominated by polythalamous calcareous forms, especially Elphidium spp. and Ammonia beccarii (L.). Comparatively low numbers in highly loaded tanks resulted in a significant negativ treatment effect for juvenile bivalves and polythalamous arenaceous foraminiferans (Table 2).

Ostracods and kinorhynchs (Fig. 4) showed the highest numbers in controls and low to moderate loadings and very low values in the 3 most highly loaded tanks from January 1982 on. During the last year not a single ostracod was found in these tanks. The Spearman's rank correlation indicated a significant treatment effect for kinorhynchs during the last year, but for ostracods only during the first year (Table 2). However, a significant difference between the highest loadings $(8 x, 16 x$, $32 \times$ ) and the other tanks (Mann-Whitney U-test, $p<$ 0.05 ) indicated a treatment effect during the last year as well. Harpacticoid copepods (Fig. 3) also showed peak values in low to moderately loaded tanks. On most occasions lower numbers of adults and copepodites were noted in tanks with higher nutrient loadings $(8 \times, 16 \times$ and $32 \times)$, which thereby differed significantly from controls and low to moderate loadings combined (Mann-Whitney U-test, $p<0.05$ ).

The juvenile polychaetes in the meiofauna were the same species that dominated the macrofauna. The abundance of juvenile polychaetes was initially low in all tanks, and remained so in the control and $1 \times$ tanks throughout the experiment (Fig. 5). In the $32 \times \operatorname{tank}$ 


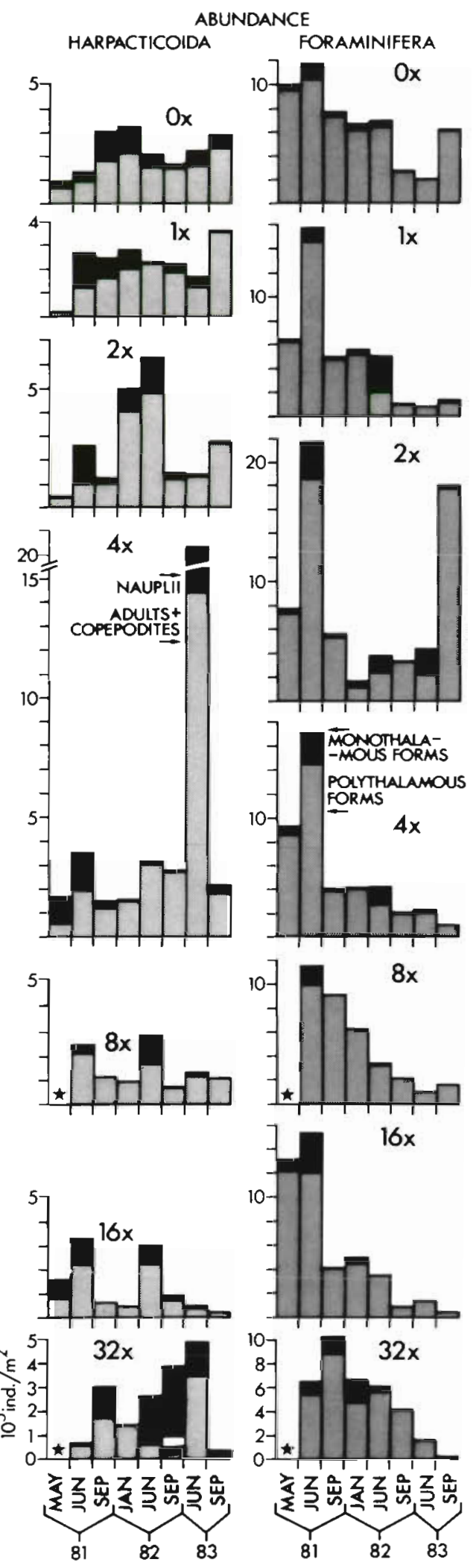

Fig. 3. Harpacticoid copepod and foraminiferan abundance $\left(10^{5}\right.$ ind. $\left.\mathrm{m}^{-2}\right)$ from the different nutrient addition treatments.

(*) No data juvenile polychaete abundance increased more than 700 -fold to September 1981, and remained high for most of the experiment. There was a significant positive correlation with nutrient loading during the first experimental year (Table 2).

\section{Meiofaunal community structure}

The first 2 components from the principal components analysis are represented in Fig. 6. Each sample is represented by the value of the nutrient loading of its tank. The larger the distance between the sample points, the lower the similarity in community structure of the samples. The eigenvectors in Table 3 show that Principal Component 1 is most heavily influenced (positively) by foraminiferans and bivalves. These declined in numbers with time (Table 2). The Principal Component 1 axis is thus to be considered mainly as a time axis, with a scale running from the right to the left. Principal Component 2 is influenced mostly by kinorhynchs and ostracods (positively), and by polychaetes and nematodes (negatively). As kinorhynchs and ostracods showed a negative, and nematodes and polychaetes a positive, response to the nutrient addition gradient (Table 2), this axis is primarily a negative nutrient load axis.

Table 3. Eigenvectors for the first 2 axes from principal components analysis of all 70 meiofauna samples from the MERL eutrophication experiment

\begin{tabular}{|lrr|} 
& PRIN 1 & PRIN 2 \\
\hline Foraminifera & & \\
$\quad$ monothalamous & 0.444 & -0.173 \\
polyth. calcareous & 0.558 & -0.145 \\
polyth. arenaceous & 0.467 & 0.056 \\
Turbellaria & 0.014 & 0.252 \\
Kinorhyncha & 0.039 & 0.549 \\
Nematoda & 0.062 & -0.449 \\
Polychaeta & -0.174 & -0.481 \\
Harpacticoida & -0.038 & 0.014 \\
Ostracoda & 0.125 & 0.386 \\
Bivalvia & 0.471 & 0.008 \\
\hline
\end{tabular}

Before the start of nutrient additions on 1 June 1981, the meiofauna communities were quite similar in all the experimental tanks, as all points from May 1981 are comparatively close together. In June 1981, after $18 \mathrm{~d}$ of nutrient addition, there is still no load-related pattern, but the swarm of points is more spread out, presumably due to a variable timing in the different tanks of the normal early summer increase of the meiofauna populations (Rudnick et al. 1985). A gradual change in meiofaunal community structure with time was found in all tanks, but by September 1982 com- 
munity structure seems to have stabilized. From September 1981 on, a structuring of the sample points within each date in response to the gradient of nutrient addition can be noticed. The most highly productive tanks, $16 \times$ and $32 \times$, fall out down the Principal Component 2 axis, and the control tanks are clustered well together in September 1982 and June 1983

\section{DISCUSSION}

\section{Response of taxonomic groups and total meiofauna}

While experimental ecosystems, such as the MERL mesocosms, allow controlled studies of the ecosystem

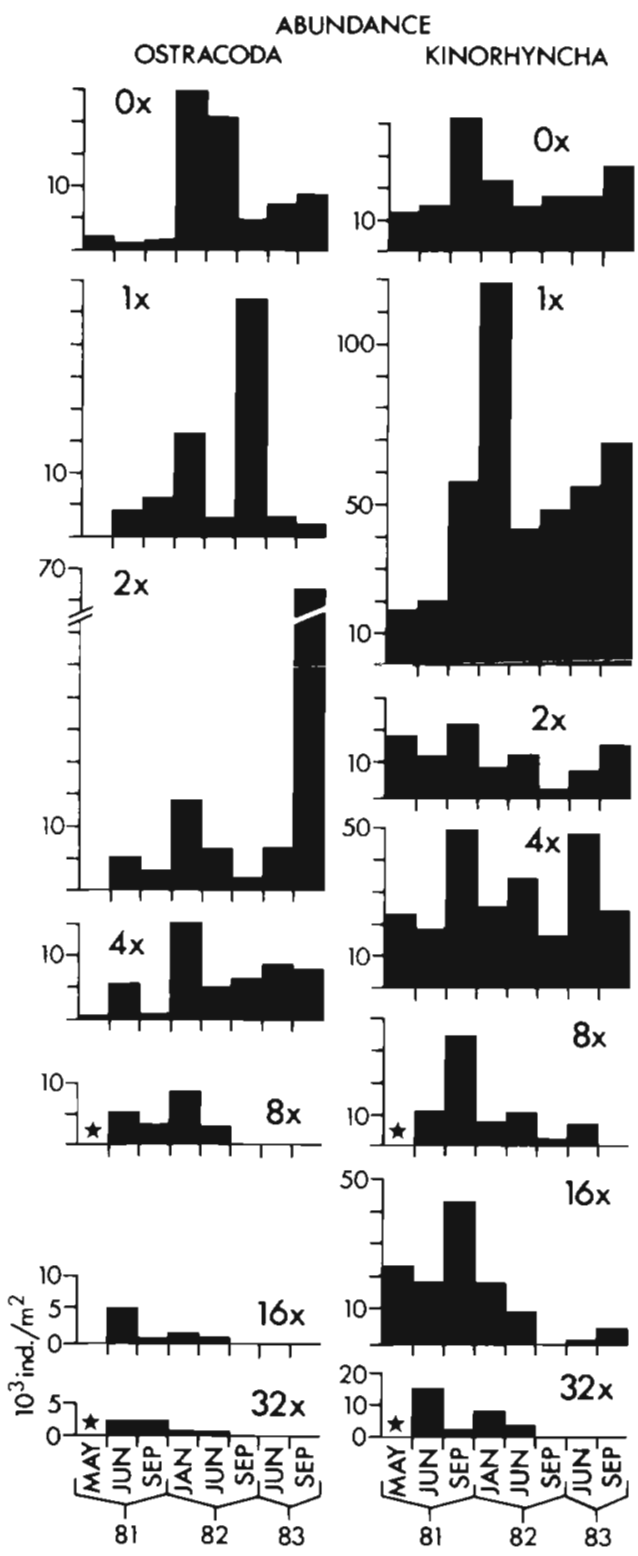

Fig. 4. Ostracod and kinorhynch abundance $\left(10^{3}\right.$ ind. $\left.\mathrm{m}^{-2}\right)$ from the different nutrient addition treatments. ( $\star$ ) No data effects of environmental stresses, such as an increased nutrient input, they must nevertheless be simplifications of nature. Thus, nutrients were added as inorganic salts, whereas real sewage contains further nutrients in particulate and organic forms (e.g. Nixon 1981). Away from the zone of primary organic enrichment such nutrients will, however, mainly affect ecosystem processes only after remineralization to the inorganic form, making this a justifiable simplification. Furthermore, the dose-response experimental design did not allow for replication of the individual load levels. The absence in the tanks of large natural predators seems to have allowed individual tanks to develop aberrant macrobenthic assemblages, such as the Mulinia pavement and a dense population of the mud anemone Cerianthiopsis americanus (Verrill) in the $8 \times \operatorname{tank}$, or the dense populations of the epibenthic shrimp Crangon septemspinosa (Say) present at times in some tanks (Nixon et al. 1986). Such deviations may be due to initial stochastic differences between tanks in their benthic community composition, and are likely to increase in importance with time. Thus, the results from the first experimental year are likely to be a better indicator of meiofauna response to eutrophication in nature than those of the second year.

While the water column biology of the MERL tanks showed clear dose-response relationships of the expected type throughout the experiment (Nixon et al. 1986), the benthic response was less clear. The absence of a significant dose-effect response of the total benthic meiofauna, in terms of abundance or biomass (Table 2), is a remarkable result in view of the massive nutrient enrichment of the most heavily loaded tanks. In fact, the meiofauna showed a gradually decreasing abundance and biomass with time in most tanks, and especially in the control tanks (Table 2). Since the length of the experiment far exceeded the generation time of most meiofaunal organisms, this decrease cannot be explained as a simple gradual die-off

Nevertheless, most meiofauna taxa showed some response to the nutrient enrichment gradient. Nematode abundance, and thus also total meiofauna abundance, tended to peak in highly productive tanks $(4 \times, 16 \times$ and $32 \times)$ in June (Fig. 2), in good agreement with the seasonal dynamics of the natural meiofauna community at the sediment-collection site (Rudnick et al. 1985). In June 1983 increased total abundances were found in the $4 \times, 16 \times$ and $32 \times$ tanks, whereas in June 1982 a very high abundance was noted only in the $16 \times$ tank. This pattern may be connected to the high numbers of the epibenthic sand shrimp Crangon septemspinosa present at times in the $4 \times$ and $16 \times$ tanks (Nixon et al. 1986). Crangon crangon is a heavy predator on macrofaunal polychaetes, but does not notice- 
ably affect the abundance of benthic meiofauna (Reise 1979). It seems therefore likely that predation by the dense populations of Crangon had a strong negative influence on the populations of the dominating polychaete species in the tanks, the capitellid Mediomastus ambiseta, and the spionids Streblospio benedicti and Polydora ligni. M. ambiseta is a nonselective, sub-surface deposit feeder (Fauchald \& Jumars 1979), which has been reported to cause a dramatic decline in meiofauna (mainly nematode) numbers in microcosms (Federle et al. 1983). The 2 spionids $S$. benedicti and $P$. ligni may likewise influence the meiofauna negatively through their feeding behaviour (Watling 1975, Dauer et al. 1981). The dominant polychaetes in the tanks thus presumably competed with or preyed upon meiofauna, and the net effect of Crangon predation would be to facilitate an increase of meiofauna populations in response to the nutrient enrichment by reducing the polychaete populations, e.g. in the $16 \times$ tank in June 1982 and 1983 and in the $4 \times$ tank in June 1983 (Frithsen et al. 1985d). In the $32 \times$ tank, where high nematode numbers in June 1983 coexisted with a comparatively dense population of the facultatively suspension-feeding (Levin 1986) $S$. benedicti, the higher food availability (Table 1) may have alleviated competition.

Several crustacean groups increased in moderately enriched tanks, but showed very low numbers in the 3 highest nutrient loadings in 1982 and 1983, e.g. planktonic copepods (Sullivan \& Ritacco 1985a, b), benthic amphipods (Frithsen et al. 1985d) and ostracods (Fig. 4). Sullivan \& Ritacco (1985b) concluded that un-ionized ammonia concentrations of more than $1.0 \mu \mathrm{mol} \mathrm{l}^{-1}$, present at times in the $16 \times$ and $32 \times$ tanks, and once in spring 1982 in the $8 \times$ tank, were toxic to the copepods. This may have been the case also for the ostracods in the MERL tanks, but the abundance of benthic harpacticoids was not negatively affected at times of high unionized ammonia concentrations in the water column. Both ostracods and harpacticoids are sensitive to low oxygen concentrations (e.g. Elmgren 1975), which may well have occurred at times in the sediment of the highly productive $16 \times$ and $32 \times$ tanks, even though total water column anoxia was noted only once, in the $32 \times \operatorname{tank}$ in August 1982. If the overlying water is well oxygenated, however, some species of harpacticoids can be favoured by even higher concentrations of sediment organic carbon than found in the $32 \times$ tank (Gee et al. 1985, Moore \& Pearson 1985).

Foraminiferans and juvenile bivalves showed decreasing trends in abundance throughout the experiment (Table 2). This was probably caused by a combination of low rates of reproduction in the tanks and of recruitment from outside. Foraminiferans, especially polythalamous forms, have been shown to be compara-

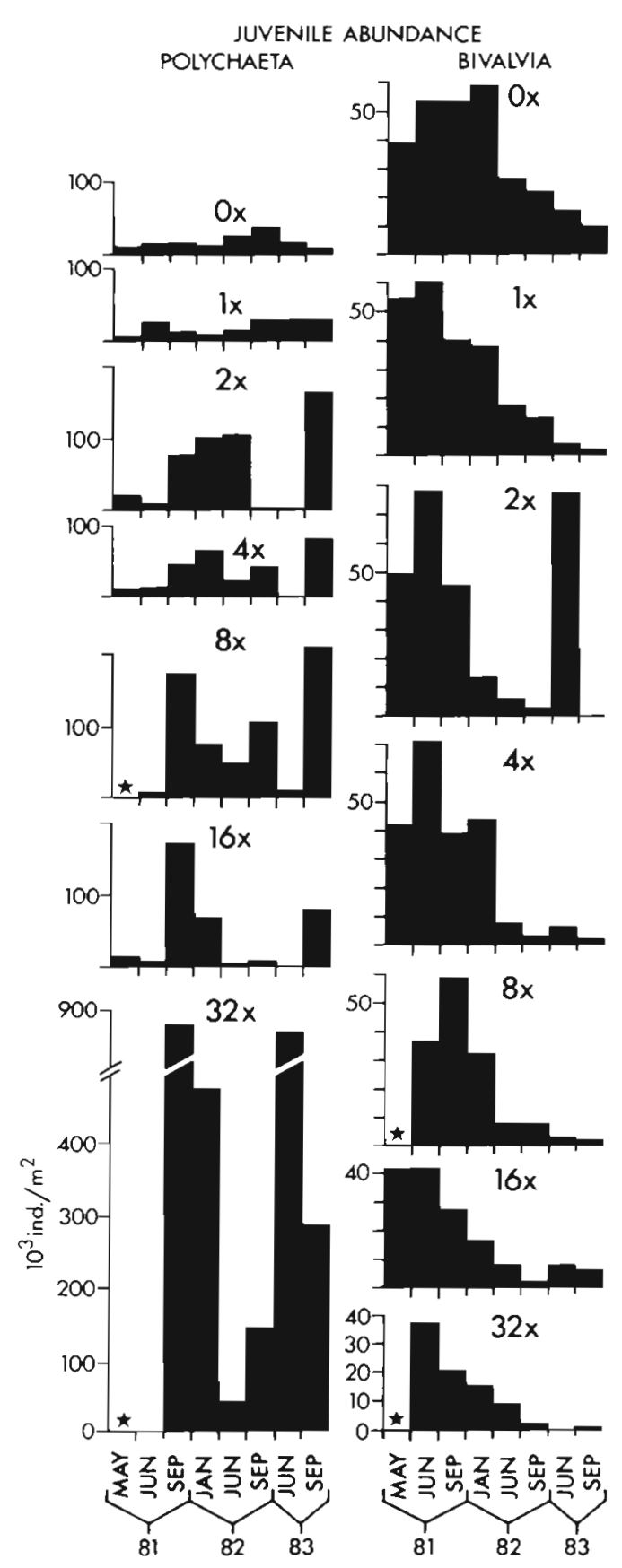

Fig. 5. Juvenile polychaete and bivalve abundance $\left(10^{3}\right.$ ind. $\mathrm{m}^{-2}$ ) from the different nutrient addition treatments. ( $\star$ ) No data

tively slow colonizers of azoic sediments (Wefer \& Richter 1976, Sherman \& Coull 1980, Widbom 1983), with a low tendency for becoming resuspended from the sediment and transported through the water column. The meiofaunal bivalves were dominated by Nucula annulata. Nucula spp. have a direct release of benthic juveniles or just a short lecithotrophic larval stage (Sastry 1979), making recruitment particularly dependent on within-tank reproduction. The abundance and bio- 
mass of adult $N$. annulata did not decline as much as for juveniles in the meiofauna fraction (Frithsen et al. 1985d), thus indicating populations of large, old specimens, not reproducing in the tanks.

\section{What limited the meiofauna populations?}

Recently, changes under eutrophication in freshwater pelagic ecosystems have been discussed in terms of bottom-up control, from increased production, alleviating resource limitation of trophic levels, or topdown control, from changes in top-predator abundance, giving rise to trophic interactions cascading down the trophic chain. McQueen et al. (1986) suggest that bottom-up (producer) controls are most influential at lower trophic levels, top-down (consumer) controls at higher trophic levels. The same types of control may be expected to operate on the benthic fauna.

In nature, a positive correlation between biomass of benthic meiofauna and productivity has been demonstrated in areas of low benthic food availability, such as the deep sea (Thiel 1983) and the Baltic Sea (Elmgren 1978). In the MERL tanks, where even the control tanks are quite productive, no such general relationship could be detected. In fact, Rudnick et al. (1985) found the meiofauna community at the sediment collection site in mid Narragansett Bay the densest ever recorded in subtidal waters. They found clear peaks in abundance and biomass of practically all meiofauna taxa in June, which they suggested was due to increasing temperature in combination with excess food resources accumulated in the sediment during the winter-spring period. In the MERL eutrophication experiment, gradually increasing values of sediment carbon up the gradient of nutrient enrichment were obtained only in spring and early summer (Table 1), indicating an enhanced accumulation of organic matter derived from the spring bloom, especially in highly loaded tanks. This is supported by a radio-tracer experiment in one MERL mesocosm, where Rudnick \& Oviatt (1986) found a time lag of several months between the deposition and mineralization of phytoplankton detritus, derived from the winter-spring bloom. In accordance whith this pattern, meiofauna biomass peaked in some loaded tanks in June (Fig. 2). Rudnick et al. (1985) proposed food limitation as a possible explanation for the rapid seasonal decline of meiofauna and macrofauna numbers in late summer, a decline found also in the MERL tanks (Frithsen et al. 1985a, this paper).

Altogether, this suggests that the lack of an overall response of total meiofauna to the gradient of nutrient enrichment was due primarily to the absence during most of the year of a gradient in enrichment of the sediment corresponding to the enrichment of the water
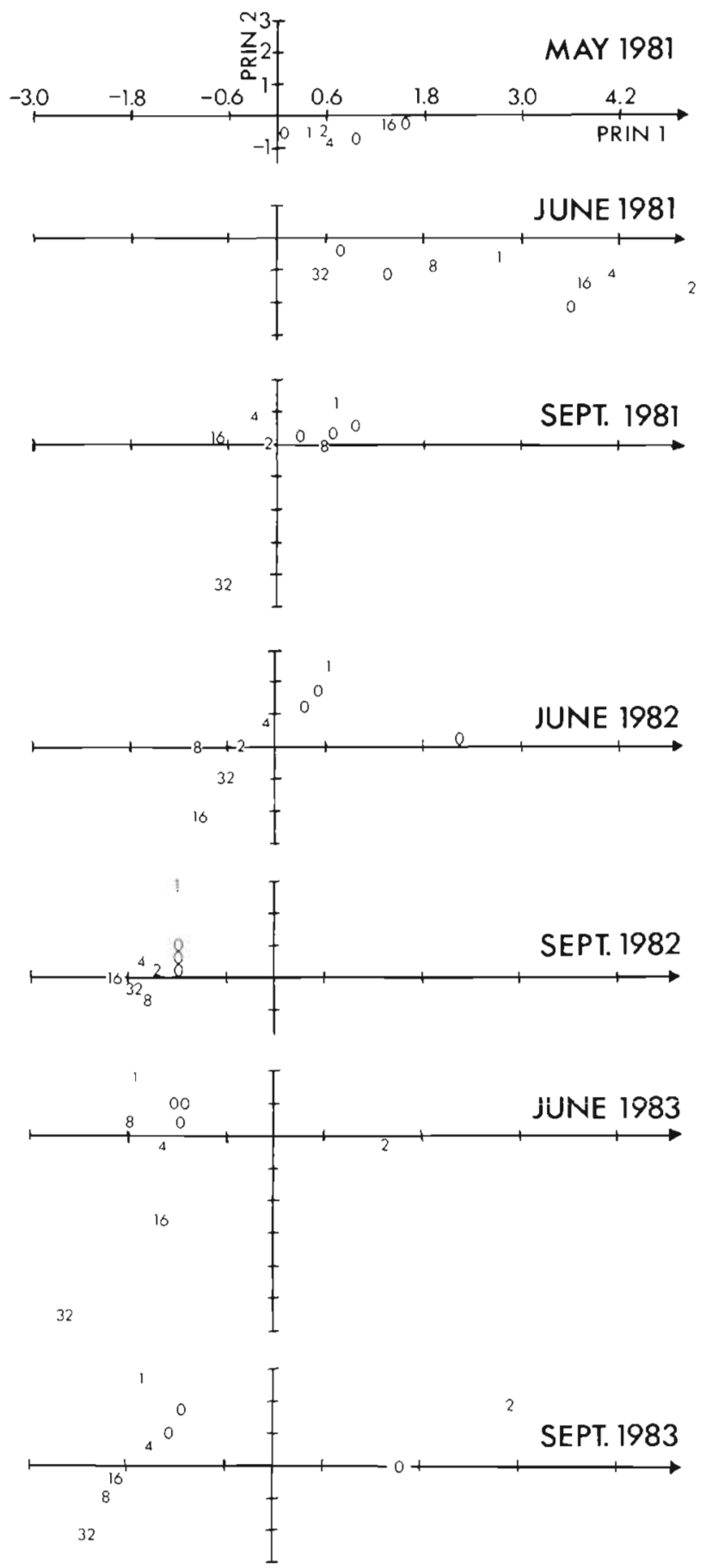

Fig. 6. Output from principal components analysis, showing differences between overall structure of the meiofauna communities in the different experimental tanks (see text for explanation). Each tank is represented by a figure indicating the nutrient loading in one coordinate system each for all June and September sampling occasions, together with the initial sampling in May 1981. PRIN: principal component

column. The meiofauna peaks in some loaded tanks in June, when enrichment of the sediment was evident, indicate the importance of food availability as one factor controling the meiofauna populations. But as not 
all loaded tanks showed an increased meiofauna biomass in June, and as the $32 \times$ tank, where the sediment carbon content was enhanced also during other periods, did not always show an increased biomass, other factors must also have been of importance. Presumably, the meiofauna populations were controlled by a combination of food availability, of particular importance in most tanks in autumn and winter, and biological interactions, such as predation and interference competition from the macrobenthos, which often counteracted the positive effect of an organic enrichment.

The pattern of meiofauna community response to nutrient enrichment thus seems to call for explanations in terms of both bottom-up (producer) and top-down (consumer) controls. The topdown control seems to have become increasingly important with time in the MERL tanks, where larger predators, such as fish and large decapods, were excluded, allowing dense populations of intermediate-sized predators, such as Crangon, to develop in some tanks (Nixon et al. 1986).

\section{Benthic meiofauna as indicator of organic enrichment}

Several papers have evaluated benthic meiofauna as an indicator of pollution. Often the importance of species determinations have been stressed, e.g. concerning nematodes (Shaw et al. 1983, Platt et al. 1984) and harpacticoids (Heip 1980). But because of the time and expertise needed for species determination of meiofauna, the analysis will normally have to stop at major taxa in practical environmental quality assessment (cf. Raffaelli 1982). In the MERL eutrophication experiment clear differences in response were detected between major meiofaunal taxa, resulting in a changed community structure.

The ratio of nematode to copepod numbers has been proposed as a useful index for the monitoring of organic pollution on beaches (Raffaelli \& Mason 1981, Raffaelli 1982), a proposal which has been questioned in several later papers (e.g. Coull et al. 1981, Lambshead 1984). Amjad \& Gray (1983) calculated this ratio along a known gradient of organic enrichment in sublittoral soft sediment in Oslofjord, Norway, and found good agreement with the original proposal. However, contradictory results have been reported from sublittoral soft sediments, with increasing copepod densities, causing decreasing nematode/copepod ratios, associated with increasing organic enrichment (Vidakovic 1983, Gee et al. 1985, Moore \& Pearson 1985). In the MERL eutrophication experiment, nematode/copepod ratios showed a significant positive correlation with nutrient loading (Table 3) and sediment carbon content (Spearman's rank correlation, $r_{S}=$
$0.882, p=0.013)$, which lends some support to the use of this ratio as an indicator of organic enrichment. But opportunistic harpacticoids are often the first colonizers of new habitats (Scheibel 1974, Chandler \& Fleeger 1983, Widbom 1983) and the first meiofaunal group to recover from toxic pollution (e.g. oil spills; Elmgren et al. 1983). In such cases a low nematode/copepod ratio indicates a habitat in the early stages of recovery from severe perturbation, not an undisturbed habitat. If the nematode/copepod ratio is used, it should therefore be interpreted in the light of the full meiofauna community composition.

We conclude that the gross taxonomic composition of benthic meiofauna communities can be used as an indicator of organic enrichment, caused by eutrophication. The intricate relations between bottom-up control, by food availability, and top-down control from the macrofauna, that can be surmised for the meiofauna in the MERL tanks, suggest, however, that meiofaunal data are best evaluated together with macrofaunal data, when assessing the eutrophication status of an area. Since the macrofauna is comparatively well understood as an indicator of organic enrichment (e.g. Pearson \& Rosenberg 1978), adding meiofaunal data in routine assessment may often be worth the added effort only in areas where the macrobenthos is reduced in species richness, such as the Baltic Sea or areas affected by hypoxia (e.g. Elmgren 1975).

Acknowledgements. We are grateful to the MERL staff, especially C. A Oviatt and J. B. Frithsen, for providing samples, environmental data and ideas. Drafts were reviewed also by D. T. Rudnick, S. Hansson and U. Larsson. A.-S. Matthiesen advised on statistics. Financial support was provided by the Andrew Mellon Foundation through MERL, and by the Swedish Natural Science Research Council. The MERL eutrophication experiment was funded by the United States Environmental Protection Agency (Grants CR-810265 and CR807795)

\section{LITERATURE CITED}

Amjad, S., Gray, J. S. (1983). Use of the nematode-copepod ratio as an index of organic pollution. Mar. Pollut. Bull. 14: $178-181$

Chandler, G. T., Fleeger, J. W (1983). Meiofaunal colonization of azoic estuarine sediment in Louisiana: mechanisms of dispersal. J. exp. mar. Biol. Ecol. 69: 175-188

Coull, B. C., Hicks, G. R. F., Wells, J. B. J. (1981). Nematode/ copepod ratios for monitoring pollution: a rebuttal. Mar. Pollut. Bull. 12: 378-381

Dauer, D. M., Maybury, C. A., Ewing, R. M. (1981). Feeding behavior and general ecology of several spionid polychaetes from the Chesapeake Bay. J. exp. mar. Biol. Ecol. 54: 21-38

Donaghay, P. (1984). Utility of mesocosms to assess marine pollution. In: White, H. (ed.) Concepts in marine pollution measurements. Maryland Sea Grant College, College Park, Maryland, p. 589-620 
Elmgren, R. (1973). Methods of sampling sublittoral soft bottom meiofauna. Oikos Suppl. 15: 112-120

Elmgren, R. (1975). Benthic meiofauna as indicator of oxygen conditions in the northern Baltic proper Merentutkimuslait. Julk. 239: 265-271

Elmgren, R. (1978). Structure and dynamics of Baltic benthos communities, with particular reference to the relationship between macro- and meiofauna. Kieler Meeresforsch., Sonderh. 4: 1-22

Elmgren, R., Hansson, S., Larsson, U., Sundelin, B., Boehm, P. D. (1983). The 'Tsesis' oil spill: acute and long-term impact on the benthos. Mar. Biol. 73: 51-65

Fauchald, K., Jumars, P. A. (1979). The diet of worms: a study of polychaete feeding guilds. Oceanogr. mar. biol. A. Rev. 17: $193-284$

Federle, T W., Livingston, R. J., Meeter, D. A., White, D. C. (1983). Modifications of estuarine sedimentary microbiota by exclusion of epibenthic predators. J. exp. mar. Biol. Ecol. 73: 81-94

Frithsen, J. B., Elmgren, R., Rudnick, D. T. (1985a). Responses of benthic meiofauna to long-term low-level additions of No. 2 fuel oil. Mar. Ecol. Prog. Ser. 23: 1-14

Frithsen, J. B., Keller, A. A., Pilson, M. E. Q. (1985b). Effects of inorganic nutrient additions in coastal areas: a mesocosm experiment. Data report, Vol. 1. MERL Series, Report No. 3, Univ. Rhode Island

Frithsen, J. B., Lane, P. A., Keller, A. A., Pilson, M. E. Q. (1985c). Effects of inorganic nutrient additions in coastal areas: a mesocosm experiment. Data report, Vol. 2. MERL Series, Report No. 4, Univ. Rhode Island

Frithsen, J. B., Keller, A. A., Pilson, M. E. Q. (1985d). Effects of inorganic nutrient additions in coastal areas: a mesocosm experiment. Data report, Vol. 3. MERL Series, Report No. 5, Univ. Rhode Island

Frithsen, J. B., Rudnick, D. T., Elmgren, R. (1983). A new, flowthrough corer for the sampling of surface sediments. Hydrobiologia 99: 75-79

Gee, J. M., Warwick, R. M., Schaaning, Mi., Berge, J. A., Ambrose, W. G. (1985). Effects of organic enrichment on meiofaunal abundance and community structure in sublittoral soft sediments. J. exp. mar. Biol. Ecol. 91: 247-262

Goldberg, E. D. (1982). Problems or non-problems. Mar. Pollut. Bull. 13: 1 (Editorial)

Grassle, J. F., Grassle, J. P., Brown-Leger, L. S., Petrecca, R. F., Copley, N. J. (1985). Subtidal macrobenthos of Narragansett Bay. Field and mesocosm studies of the effects of eutrophication and organic input on benthic populations. In: Gray, J. S., Christiansen, M. E. (eds.) Marine biology of polar regions and effects of stress on marine organisms. Proceedings 18th European Symposium on Marine Biology. John Wiley, New York, p. 421-434

Heip, C. (1980). Meiobenthos as a tool in the assessment of marine environmental quality. Rapp. P.-v. Réun. Cons. int. Explor. Mer 179: 182-187

Hunt, C. L., Smith, D. L. (1983). Remobilization of metals from polluted marine sediments. Can. J. Fish. Aquat. Sci. 40 (Suppl. 2): 132-142

Lambert, C. E., Oviatt, C. A. (1986). Manual of biological and geochemical techniques in coastal areas. MERL Series, Report No. 1, 2nd edn. Univ. Rhode Island

Lambshead, P. J. D. (1984). The nematode/copepod ratio. Some anomalous results from the Firth of Clyde. Mar. Pollut. Bull. 15: 256-259

Lassig, J. (ed.) (1987). First periodic assessment of the state of the marine environment of the Baltic Sea, 1980-1985; Background document. Baltic Sea Environ. Proc. 17B

Levin, L. A. (1986). Effects of enrichment on reproduction in the opportunistic polychaete Streblospio benedicti (Webster): a mesocosm study. Biol. Bull. mar biol. Lab., Woods Hole 171: 143-160

McQueen, D. J., Post, J. R., Mills, E. L. (1986). Trophic relations in freshwater pelagic ecosystems. Can. J. Fish. Aquat. Sci. 43: 1571-1581

Moore, C. G., Pearson, T. H. (1985). Response of a marine copepod assemblage to organic enrichment. Syllogeus 58 : 369-373

Nixon, S. W. (1981). Remineralization and nutrient cycling in coastal marine ecosystems. In: Neilson, B. J., Cronin, L. E. (eds.) Estuaries and nutrients. Humana Press, Clifton, New Jersey, p. 111-138

Nixon, S. W., Alonso, D., Pilson, M. E. Q., Buckley, B. A. (1980). Turbulent mixing in aquatic microcosms. In: Giesy, J. P. (ed.) Microcosms in ecological research. DOE Symp. Ser. 52, Georgia, Nov 8-19, 1978, Conf. 781101, Nat. Tech. Inf. Serv., p. 818-849

Nixon, S. W., Oviatt, C. A., Frithsen, J. B., Sullivan, B. K. (1986). Nutrients and the productivity of estuarine and coastal marine ecosystems. J. Limnol. Soc. sth. Afr. 12 (1/2): 43-71

Nixon, S. W., Pilson, M. E. Q., Oviatt, C. A., Donaghay, P., Sullivan, B., Seitzinger, S., Rudnick, D., Frithsen, J. (1984). Eutrophication of a coastal marine ecosystem - an experimental study using the MERL microcosms. In: Fasham, M. J. R. (ed.) Flows of energy and materials in marine ecosystems: theory and practice. Plenum Press, New York, p. $105-135$

Officer, C. B., Biggs, R. B., Taft, J. L., Cronin, E., Tyler, M. A., Boynton, W. R. (1984). Chesapeake Bay anoxia: origin, development, and significance. Science 223: 22-27

Oviatt, C. A., Keller, A. A., Sampou, P. A., Beatty, L. L. (1986). Patterns of productivity during eutrophication: a mesocosm experiment. Mar. Ecol. Prog. Ser. 28: 69-80

Pearson, T H., Rosenberg, R. (1978). Macrobenthic succession in relation to organic enrichment and pollution of the marine environment. Oceanogr. mar. biol. A. Rev. 16: 229-311

Pilson, M. E. Q., Oviatt, C. A., Nixon, S. W. (1980). Annual nutrient cycles in a marine microcosm. In: Giesy, J. P. (ed.) Microcosms in ecological research. DOE Symp. Ser. 52, Augusta, Georgia, Nov 8-19, 1978, Conf. 781101, Nat. Tech. Inf. Serv., p. 753-778

Platt, H. M., Shaw, K. M., Lambshead, P. J. D. (1984). Nematode species abundance patterns and their use in the detection of environmental perturbations. Hydrobiologia 118: 59-66

Raffaelli, D. G. (1982). An assessment of the potential of major meiofauna groups for monitoring organic pollution. Mar. Environ. Res. 7: 151-164

Raffaelli, D. G., Mason, C. F. (1981). Pollution monitoring with meiofauna, using the ratio of nematodes to copepods. Mar. Pollut. Bull. 12: 158-163

Reise, K. (1979). Moderate predation on meiofauna by the macrobenthos of the Wadden Sea. Helgoländer wiss. Meeresunters. 32: 453-465

Rosenberg, R. (1985). Eutrophication - the future marine coastal nuisance. Mar. Pollut. Bull. 16: 227-231

Rudnick, D. T., Oviatt, C. A. (1986). Seasonal lags between organic carbon deposition and mineralization in marine sediments. J. mar. Res. 44: 815-837

Rudnick, D. T., Elmgren, R., Frithsen, J. B. (1985). Meiofaunal prominence and benthic seasonality in a coastal marine ecosystem. Oecologia (Berl.) 67: 157-168

Said, R. (1951). Foraminifera of Narragansett Bay. Contr. Cushman Foundation foramin Res. 2: 75-86 
SAS Institute Inc. (1982). SAS user's guide: statistics, 1982 edn. SAS Inst. Inc, Cary, North Carolina

Sastry, A. N. (1979). Pelecypoda (excluding Ostreidae). In: Giese, A. C., Pearse, J. S. (eds.) Reproduction of marine invertebrates, Vol. 5. Academic Press, New York, p. 113-341

Scheibel, W (1974). Submarine experiments on benthic colonization of sediments in the western Baltic Sea. II. Meiofauna. Mar. Biol. 28: 165-168

Shaw, K. M., Lambshead, P. J. D., Platt, H. M. (1983). Detection of pollution-induced disturbance in marine benthic assemblages with special reference to nematodes. Mar. Ecol. Prog. Ser 11: 195-202

Sherman, K. M., Coull, B. C. (1980). The response of meiofauna to sediment disturbance. J. exp. mar. Biol. Ecol. 46: $59-71$

Sokal, R. R., Rohlf, F. J. (1981). Biometrics. The principles and practice of statistics in biological research, 2 nd edn. Freeman \& Co, San Francisco

Steele, J. H. (1979). The uses of experimental ecosystems. Phil. Trans. R. Soc. Lond. B. Biol. Sci. 286: 583-595

Sullivan, B. K, Ritacco, P. J. (1985a). The response of dominant copepod species to food limitation in a coastal marine ecosystem. Arch. Hydrobiol. Beih. Ergeb. Limnol. 21: $407-418$
Sullivan, B. K., Ritacco, P. J. (1985b). Ammonia toxicity to larval copepods in eutrophic marine ecosystems: a comparison of results from bioassays and enclosed experimental ecosystems. Aquat. Toxicol. 7: 205-217

Thiel, H. (1983). Meiobenthos and nanobenthos of the deep sea. In: Rowe, G. T (ed.) The sea, Vol. 8. John Wiley and Sons, New York, p. 167-230

Vidakovic, J. (1983). The influence of raw domestic sewage on density and distribution of meiofauna. Mar. Pollut. Bull 14: $84-88$

Watling, L. (1975). Analysis of structural variations in a shallow estuarine deposit-feeding community. J. exp. mar. Biol. Ecol. 19: 275-313

Wefer, G., Richter, W. (1976). Colonization of artificial substrates by Foraminifera. Kieler Meeresforsch. Sonderh. 3 : $72-75$

Widbom, B. (1983). Colonization of azoic sediment by sublittoral meiofauna in Gullmar Fjord - Swedish west coast. In: Boutler, J. (ed.) Proceedings 17th European Marine Biology Symposium. Oceanologica Acta vol. spéc., p. 213-217

Widbom, B. (1984). Determination of average individual dry weights and ash-free dry weights in different sieve fractions of marine meiofauna. Mar. Biol. 84: 101-109

This article was submitted to the editor; it was accepted for printing on December 28,1987 